\title{
Developing Think Talk Write Strategy on Students' English Literation Capability
}

\author{
Anita Purba ${ }^{1}$, Semaria Eva Elita Girsang ${ }^{2}$ \\ ${ }^{1,2}$ Universitas Simalungun, Pematangsiantar, Indonesia \\ anit_apurba@yahoo.co.id
}

\begin{abstract}
This study aims to determine the effect of developing Think Talk Write (TTW) Strategy in increasing literation capability of English text for 4th semester students of the 2019/2020 academic year of English Study Program, Education Faculty (FKIP) - Simalungun University (USI). The development of the TTW Strategy consists of three phases, namely Think, Talk and the Writing Phase. These three phases are the independent variables of the study, while the dependent variable is literation capability. The research was conducted for 30 students. The sampling technique used saturated sampling technique. The type of data used is primary data. Data were analysed using multiple linear regression analysis method. The results of the analysis show that the Think, Talk and Writing Phases have a positive and significant effect on increasing students' literation capability in English text, both partially and simultaneously. Thus, it can be concluded that the development of the TTW Strategy has a positive and significant effect in improving students' literation capability.
\end{abstract}

Keywords

TTWstrategy, think phase; talk phase; write phase; literation capability

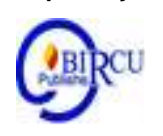

\section{Introduction}

Understanding Literation in general is the ability to access, understand, and use something intelligently through various activities, including reading, viewing, listening, writing, and / or speaking. According to UNESCO, the condition of student literation in Indonesia is very low (Kompasiana, 29 January 2019), to achieve the target of increasing literation capability, teachers are required to be more effective or creative in seeking or finding various strategies or techniques that can break the awareness and interest of students around Literation.

The Ministry of Education and Culture developed Gerakan Literasi Nasional (GLN) is the National Literation Movement which involved all stakeholders in the education sector, from the central, provincial, district / city levels, and all educational units. GLN is an effort that is carried out comprehensively to make the school as a learning organization whose students have lifelong literation capabilities.

As far as observations made by researchers, students of English Study Program are still less able to improve their literation capability, especially in writing English texts. In line with the description above, it is necessary to conduct a study in terms of developing a learning strategy, namely the TTW Strategy in the ability to write English texts for the 4th semester students of the 2019/2020 academic year.

TTW Strategies in learning are built through the process of thinking, talking/speaking and writing. With this learning strategy, students are more involved in analysing a problem and finding solutions to solve it. TTW learning strategies can develop problem-solving capability (Yamin and Ansari, 2012). TTW Strategy Development is 
intended to improve students' literation capability. The increase in abilities experienced can be seen from their learning outcomes.

The development of the TTW Strategy is carried out by dividing the learning process into three phases, namely the Think Phase, the Talk Phase and the Write Phase. Each of these phases ends with a test. The division of the learning process into several phases aims to increase student concentration so that they are more focused on each activity contained in each phase. Thus, understanding of the problem is deeper. Mayasari (2017) found that increasing learning concentration can improve learning outcomes.

Another development made in the TTW Strategy is that at the end of each learning phase a test is always held. It aims to evaluate the development experienced by each student after carrying out activities in that phase. Giving tests can also increase student motivation to obtain maximum results. The frequency of giving formative tests according to the research results of Darmayanti et.al. (2015) and Fariah and Leonard (2017) have a positive and significant effect on improving learning outcomes. The more often students are given tests, the better the learning outcomes.

The development of the TTW Strategy that is made will be tested how far it affects the improvement of students' literation capability. In this case, the Think Phase, Talk Phase and Write Phase are expected to provide their own contribution to improving each student's capability in literation.

\section{Review of Literatures}

\subsection{Literation}

According to Ane Permatasari in the Proceedings of the Language Month Seminar (2015), literation can simply be defined as the ability to read and write, known as literation. Literation is not just focused on reading and writing. Therefore, reading and writing can be said to be the basic capability that must be possessed to build complete literation capability. Reading is about understanding written text. Reading is also the window of knowledge. By reading, people may get much information by understanding the content of the text and may know everything in the world (Sipayung, 2018). Meanwhile Saragih et al (2019) defined writing is the ability to express ideas, opinions, and feelings to other parties through written language

Literacy is developed through the specific language, enabling students to understand how the English language works in different social contexts and critically assessing writers' opinions, biases and intentions, and assisting them to make sophisticated language choices in their own texts (Erwinsah et al, 2019). The opinion of Mustafa (2017) explains that literation is the ability to read, write and think critically. In its function, literation is able to influence a person's thinking, foster a critical culture to give birth to a smart and competitive society. There are several dimensions of literation according to the Ministry of Education and Culture's National Literation Movement Team (2017), namely:

1. Read and Write Literation

Reading and Writing literation is the knowledge and capability to read, write, achieve goals, develop understanding and potential, and to participate in social environments.search, process, understand and analyse information, respond to, and use written texts to

2. Numeration Literation

Numerical literation is the knowledge and capability to (a) be able to acquire, interpret, use, and communicate various kinds of mathematical numbers and symbols to solve practical problems in various contexts of everyday life; (b) can analyse the information presented in various forms (graphs, tables, charts, etc.) to make decisions. 


\section{Science Literation}

Scientific literation is knowledge and scientific capability to be able to identify questions, acquire new knowledge, explain scientific phenomena, and draw conclusions based on facts, understand the characteristics of science, build awareness of how science and technology shape the natural, intellectual and cultural environment, and increase the willingness to be involved and care in science-related issues.

4. Digital Literation

Digital literation is the knowledge and capability to use digital media, communication tools, or networks in finding, evaluating, using, making information, and utilizing it in a healthy, wise, intelligent, careful, precise and law-abiding manner in order to foster communication and interaction in daily life.

5. Financial Literation

Financial literation is the knowledge and capability to apply (a) an understanding of concepts and risks, (b) capability, and (c) motivation and understanding in order to make effective decisions in a financial context to improve financial well-being, both individually and socially, and can participate in the community environment.

6. Cultural and Citizenship Literation

Cultural literation is knowledge and capability in understanding and behaving towards Indonesian culture as a national identity. Meanwhile, civic literation is knowledge and capability in understanding the rights and obligations of citizens.

\subsection{English Text}

There are 13 types of text (Long Functional Text) in English (Anderson, 1997), namely: Narrative, Recount, Descriptive, Procedure, Report, Anecdote, Hortatory, Spoof, Explanation, Discussion, News Item, Review, and Analytical Exposition. In this study, researcher only used Explanation Text as material in implementing the TTW Strategy. Explanation Text has three important elements, namely:

1. Social Function

The social function of the Explanation Text is to explain processes related to natural phenomena, social science, and culture. This text also tells the reader why and how certain phenomena occur. This text is often found in science, geography, and history books.

2. Generic Structure

Paragraph arrangement is a pattern or flow that is presented in a stage of mapping ideas or information in a text. Paragraph arrangement of an explanation text is:

a. General statement: contains general information about the topics to be discussed in the text.

b. Sequenced explanation: contains a series of events (sequence of events) from a process which is the topic of the text. We can also explain by using questions about why and how it happened, so that the explanation we convey is more complete.

3. Language Feature.

Linguistic characteristics are the characteristics of a text that has a linguistic pattern specifically, in its delivery, this pattern can take the form of tenses, it can also be other grammar rules. The language characteristics of the Explanation Text are:

a. Chronological connection; to begin with, next, etc.

b. Passive voice pattern: to be + past perfect

c. Simple present tense 


\subsection{TTW Strategy}

One of learning strategy that can be used to increase interest in literation is the TTW Strategy. This TTW strategy is built through speaking and writing, starting with the involvement of students in thinking or having dialogue with themselves after the reading process, then speaking and sharing opinions with their friends before writing. TTW is classified as cooperative learning which means that students are put into group in which they are working together to reach the learning objectives (Purba and Girsang, 2020). There are two types of cooperative learning, namely Students Teams Achievement Division (STAD) and Teams Games Tournament (TGT) which is conducted in student groups consisting of 4-5 people per group (Ramadhani et al., 2020). In cooperative learning, students are trained to share knowledge, experiences, tasks and responsibilities (Purba et al., 2021)

According to Yamin, as quoted by Santi Hasmarani, et al in the Journal of Chemica Vol. 15 Number 1 June 2014, entitled The Effect of the TTW Strategy on the Problem Based Learning Learning Model on the Critical Thinking Capability of Class XI MS Students of SMA Negeri 2 Bulukumba, that the TTW Strategy is a strategy introduced by Huinker \& Laughlin which is basically built through thinking, Speaking and Writing. The progress flow of the TTW Strategy starts from the involvement of students in thinking or having dialogue with themselves after the reading process, then talking and sharing ideas (sharing) with friends before writing.

In Huda quoted by Risna Ratih, in the Scientific Pen Journal: Vol 2, No.1 2017 with the title Application of the TTW Type Cooperative Learning Strategy to Increase Student Activity and Learning Outcomes, the learning strategy to be applied is the Cooperative Learning type (Think Talk Write). ). TTW is a Strategy that facilitates learning to think, speak and write fluently.

Zulkarnaini in the Special Edition Journal No.2, August 2011 with the title Think Talk Cooperative Model to Improve the Ability to Write Descriptions and Critical Thinking. States that first in the Think phase, students are asked to read, take individual small notes of what is known or not. is known to be brought up on discussion forums in the talk phase. Furthermore, in the Talk phase, students form groups of 3-5 each heterogeneous group member to read small notes and change the cognitive structure of thinking solving problems. Finally, in the Write phase, students are asked to individually construct their knowledge to complete the worksheets through writing based on the insights obtained from the discussion and small notes in their group on the ability to share ideas (sharing) with their friends before writing.

\subsection{Framework}

This study aims to examine the effect of TTW Strategy Development on increasing literation capability in English texts. The development of the TTW Strategy consists of three phases, namely the Think Phase, the Talk Phase, and the Write Phase. Therefore, the independent variables of this study are the Think Phase (X1), Talk Phase (X2), and Write Phase (X3). While the dependent variable is literation capability. The research framework can be described as follows: 


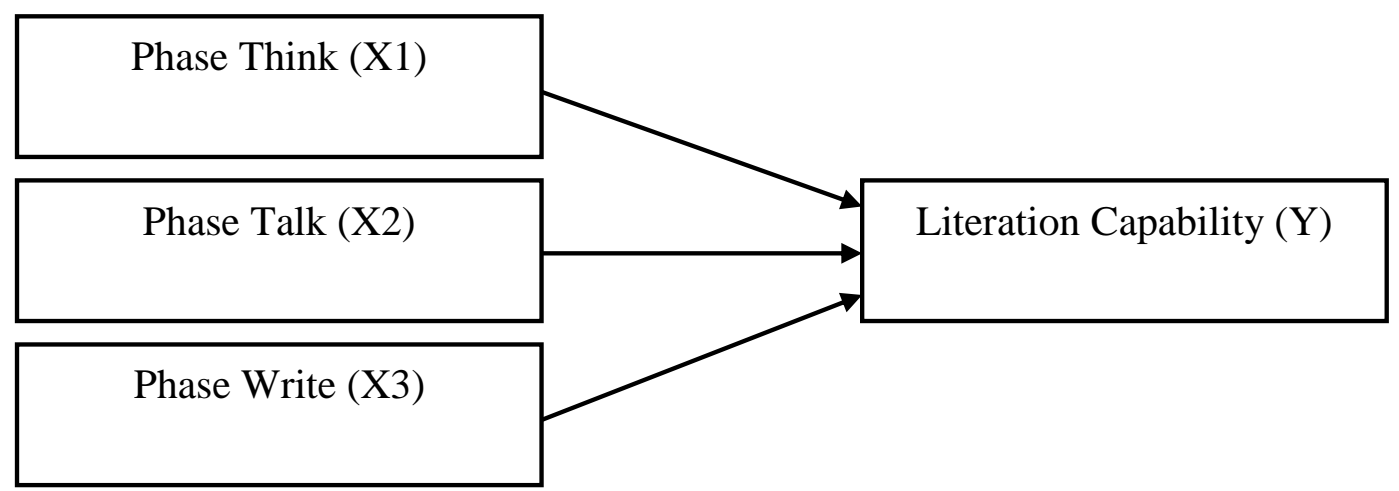

Figure 1. Framework

\subsection{Hypothesis}

The research hypothesis are:

1. The Think phase has a positive and significant effect on increasing literation capability in English text for 4th semester students of the 2019/2020 academic year English Study Program, KIP USI Pematangsiantar.

2. The Talk phase has a positive and significant effect on increasing literation capability in English text for 4th semester students of the 2019/2020 academic year English Study Program, FKIP USI Pematangsianta,.

3. The Write phase has a positive and significant effect on increasing literation capability in English text for 4th semester students of the 2019/2020 academic year English Study Program, FKIP USI Pematangsiantar.

4. The Think Phase, Talk Phase, and Write Phase have a simultaneous effect on increasing literation capability in English text for 4th semester students of the 2019/2020 academic year English Study Program, FKIP USI Pematangsiantar.

\section{Research Methods}

This research is quantitative descriptive. The research was conducted on students of English Study Program, FKIP USI Pematangsiantar for semester 4 of the 2019/2020 academic year, total 30 people. Determination of the sample using saturated sampling technique.

The type of data used in this study is primary data. The research data was obtained from the respondent's score in each phase carried out. The data collection process took the following stages of developing the TTW Strategy:

1. The first activity in the Think Phase, the researcher explains the Explanation Text material provided about Covid 19 to students accompanied by a picture, then they are asked to read and understand the material by answering comprehensive questions at the end of reading as many as 20 questions in the form of Multiple Choice online. The score of the answers is calculated by the number of correct answers multiplied by 5 points and this score becomes the variable data for X1 (Think Phase). Furthermore, each student makes individual notes of what is known (statement) or not known (question) from the text to be brought to the discussion forum in the Talk Phase.

2. Next in the Talk Phase, students are asked to form groups of 5 people (into 6 groups). In each group, they talk and discuss about the notes of each group member until all participants understand them and get answers to the questions in their notes. All conversations are recorded and will be assessed using the Speaking Rubric and this score becomes the X2 variable data (Talk Phase). 
3. Finally in the Write Phase, students are asked individually construct their knowledge and write an Explanation text according to in their own words based on the insights they get from the discussion and notes in the previous discussion group and will be assessed by looking at the Explanation Text element, namely: Social Function , Generic Structure and Language Feature. The score of this Explanation text becomes the X3 variable data (Write Phase).

4. Data variable $\mathrm{Y}$ is the score of students in writing. Students are given an Explanation Text with the title: "How Do People Get Infected by Covid-19", then they are asked to read and understand the text. After that, each student was asked to write one writing independently with the title: My Understanding about Covid-19. The writing is assessed using the Writing Rubric and the score becomes the data variable Y (Literation Ability).

Methods of data analysis using multiple linear regression analysis. The analysis begins with testing the classical assumptions. If the classical assumption test does not find problems related to the data and research model, the analysis is then continued at the hypothesis testing stage.

The classical assumption test carried out includes the normality test, multicollinearity test and heteroscedasticity test. The data normality test used the Kolmogorov-Smirnov test. The research model is declared free from normality problems if the Asyimp score. Sig. (2tailed)>0.05. Multicollinearity problems are detected by looking at the VIF score. A research model is said to be free from multicollinearity problems if the VIF score is $<10$. The heteroscedasticity test uses the Glejser test. The research model is said to be free from heteroscedasticity problems if the significance probability of each independent variable is greater than 0.05 .

The research regression equation can be written as follows:

$$
\mathrm{Y}=\mathrm{a}+\mathrm{b} 1 \mathrm{X} 1+\mathrm{b} 2 \mathrm{X} 2+\mathrm{b} 3 \mathrm{X} 3+\mathrm{e}
$$

Information:

Y: Literation Capability

$\mathrm{X} 1$ : Think phase

X2: Talk phase

X3: Write phase

a: Constants

b1,2,3: Regression coefficient

e: Standard error

\section{Results and Discussion}

\subsection{Descriptive Statistics}

Descriptive statistics are presented with the aim of showing descriptions or information related to research data. Descriptive statistical presentation can be in the form of tables, diagrams and graphs.

Table 1. Descriptive Statistics

\begin{tabular}{|l|l|l|l|l|}
\hline Variable & Minimum & Maximum & Mean & Std. Deviation \\
\hline Phase Think & 70 & 90 & 78.33 & 6.477 \\
\hline Phase Talk & 65 & 85 & 76.83 & 5.796 \\
\hline Phase Write & 70 & 85 & 79.33 & 5.683 \\
\hline Literation capability & 70 & 90 & 80.93 & 6.130 \\
\hline
\end{tabular}

Source: Data Processed (2020) 
Table 1 shows the average score of the Think Phase of students of English Study Program FKIP USI Pematangsiantar in semester 4 of the 2019/2020 academic year of 78.33. This shows that the average reading ability average of the 4th semester students of English Study Program FKIP USI Pematangsiantar is good. Furthermore, the highest score for the Think Phase is 90, while the lowest score is 70 with a standard deviation of 6.477.

The average score of the Talk Phase students of the English Study Program, FKIP USI Pematangsiantar, semester 4 of the 2019/2020 school year is 76.83. This shows that on average, the speaking ability of the 4th semester students of the English Study Program FKIP USI Pematangsiantar is good. Furthermore, the highest score for Phase Talk is 85, while the lowest score is 65 with a standard deviation of 5.796 .

The average score of the Write Phase students of the English Study Program, FKIP USI Pematangsiantar, semester 4 of the 2019/2020 school year is 79.33. This shows that on average, the writing capability of the 4th semester students of the English Study Program, FKIP USI Pematangsiantar, are classified as good. Furthermore, the highest score of Think Phase is 85 , while the lowest score is 70 with a standard deviation of 5.683.

The average score of literation abilities of students in the English Study Program, FKIP USI Pematangsiantar, semester 4 of the 2019/2020 school year is 80.93. This shows that on average, the literation capability of students in the 4th semester of English Study Program, FKIP USI Pematangsiantar are very good. Furthermore, the highest score of Literation ability is 90 , while the lowest score is 70 with a standard deviation of 6.130 .

\subsection{Classic Assumption Test}

a. Normality Test

Testing data normality in this study using the Kolmogorov-Smirnov Test. The data is said to be normally distributed if the Asyimp score. Sig. (2-tailed)>0.05. The results of the normality test are presented in Table 2 below:

Table 2. Normality Test Results

One-Sample Kolmogorov-Smirnov Test

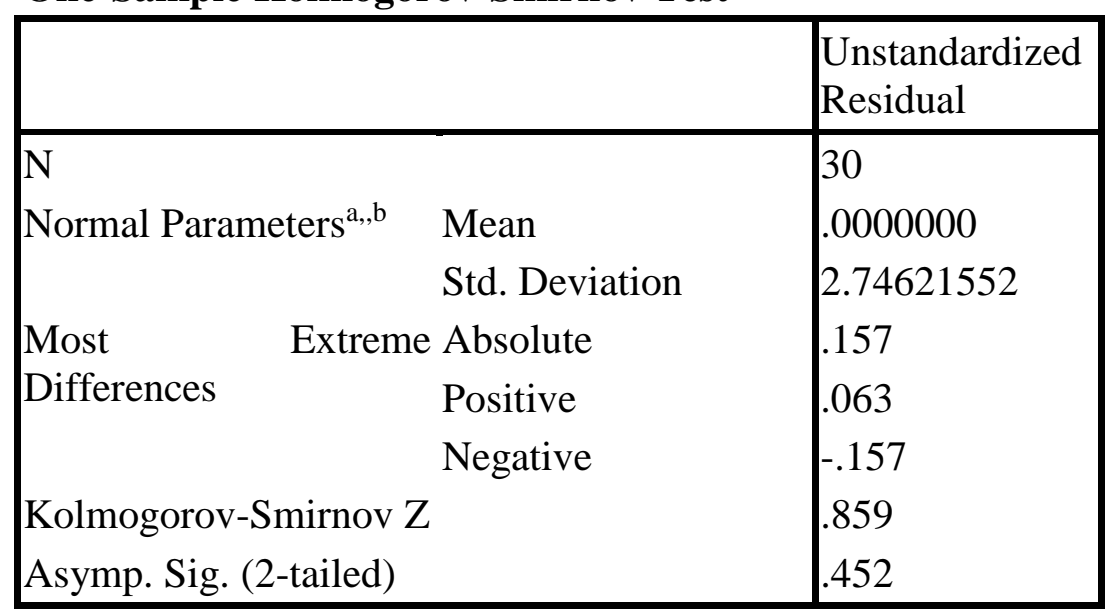

a. Test distribution is Normal.

b. Calculated from data.

Source: Data Processed (2020)

The test results show that the Asymp. Sig. (2-tailed) of 0.452. This score is greater than 0.05 . Thus it can be concluded that the research data is normally distributed. 


\section{b. Multicollinearity Test}

The multicollinearity problem in this study was detected by looking at the VIF score. A research model is said to be free from multicollinearity problems if the VIF score is $<10$.

Table 3. Multicollinearity Test Results

\begin{tabular}{|l|l|l|}
\hline Variable & VIF & Explanation \\
\hline Phase Think & 1,953 & There is no Multicollinearity problem \\
\hline Phase Talk & 2,290 & There is no Multicollinearity problem \\
\hline Phase Write & 2,127 & There is no Multicollinearity problem \\
\hline
\end{tabular}

Source: Data Processed (2020)

The test results show that the VIF score of all independent variables is less than 10 . Thus, it can be concluded that the research model is free from multicollinearity problems.

\section{c. Heteroscedasticity Test}

Testing the heteroscedasticity problem in this study using the Glejser test. The model is said to be free from heteroscedasticity problems if the probability of the significance of the independent variable is $>0.05$.

Table 4. Heteroscedasticity Test Results

\begin{tabular}{|l|l|l|}
\hline Variable & Sig. & Explanation \\
\hline Phase Think & 0,811 & There is no Heteroscedasticity problem \\
\hline Phase Talk & 0,985 & There is no Heteroscedasticity problem \\
\hline Phase Write & 0,468 & There is no Heteroscedasticity problem \\
\hline
\end{tabular}

Source: Data Processed (2020)

The test results show that the probability of the significance of all independent variables is greater than 0.05 . Thus, it can be concluded that the research model is free from heteroscedasticity problems.

\subsection{Hypothesis Test}

a. Determination Coefficient Test (R2)

The coefficient of determination shows how much the ability of the independent variables to explain the variation in the dependent variable. The coefficient of determination is indicated by the adjusted $\mathrm{R} 2$ score.

Table 5. The Result of Determination Coefficient Test

Model Summary ${ }^{\mathrm{b}}$

\begin{tabular}{|l|l|l|l|l|}
\hline Model & $R$ & R Square & $\begin{array}{l}\text { Adjusted } \\
\text { Square }\end{array}$ & $\begin{array}{l}\text { Std. Error of the } \\
\text { Estimate }\end{array}$ \\
\hline 1 & $.873^{\mathrm{a}}$ & .761 & .753 & 2.535 \\
\hline
\end{tabular}

a. Predictors: (Constant), Developing TTW Strategy

b. Dependent Variable: Literation Capability

Source: Data Processed (2020)

The adjusted R2 score is known to be 0.776. This means that the Think Phase, Talk Phase and Write Phase are able to explain the variation in Literation capability by $77.6 \%$, while the remaining $22.4 \%$ are influenced by other variables not included in the research model. 


\section{b. Simultaneous Significance Test (Test F)}

F test is conducted to test the simultaneous effect of independent variables on the dependent variable. All independent variables are said to have a simultaneous effect on the dependent variable if the probability score of the $\mathrm{F}$ test is less than 0.05 .

Table 6. F Test Results

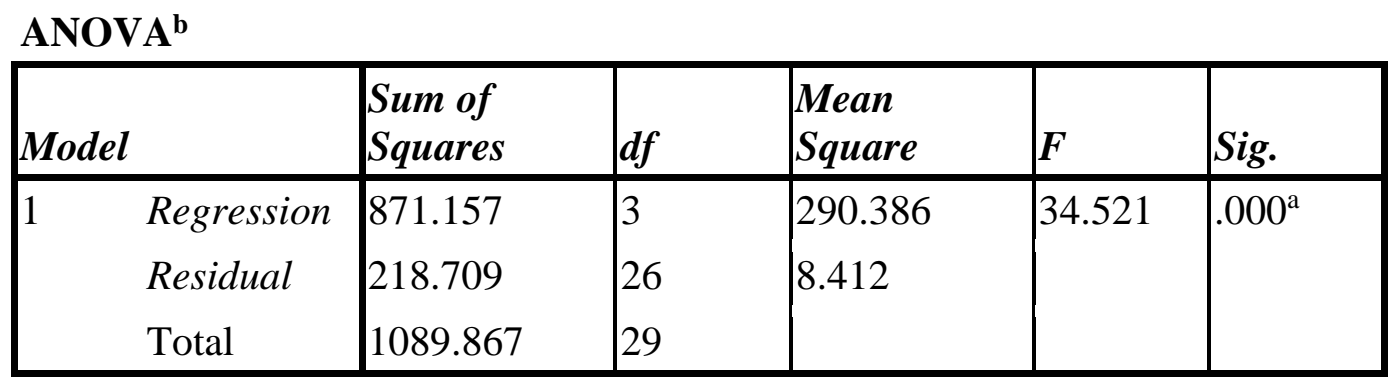

a. Predictors: (Constant), Phase Write, Phase Think, Phase Talk

b. Dependent Variable: Literation Capability

Source: Data Processed (2020)

The results of the analysis show that the significance probability score of the $\mathrm{F}$ test is 0,000 . The significance probability score is smaller than 0.005 . Thus, it can be concluded that the Think Phase, Talk Phase, and Write Phase simultaneously influence literation capability.

\section{c. Partial Significance Test (t Test)}

The $t$ test aims to test whether the proposed hypothesis is accepted or rejected. The results of the $t$ test are presented in Table 7 below:

Table 7. $\mathrm{t}$ test results

Coefficients ${ }^{a}$

\begin{tabular}{|c|c|c|c|c|c|c|}
\hline \multirow{2}{*}{\multicolumn{2}{|c|}{ Model }} & \multicolumn{2}{|c|}{$\begin{array}{l}\text { Unstandardized } \\
\text { Coefficients }\end{array}$} & \multirow{2}{*}{ 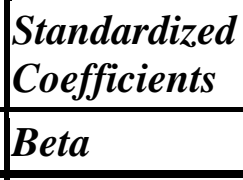 } & \multirow[b]{2}{*}{$t$} & \multirow[b]{2}{*}{ Sig. } \\
\hline & & $B$ & Std. Error & & & \\
\hline \multirow[t]{4}{*}{1} & (Constant) & -1.404 & 8.115 & & -.173 & .864 \\
\hline & $\begin{array}{l}\text { Phase } \\
\text { Think }\end{array}$ & .247 & .116 & .261 & 2.130 & .043 \\
\hline & Phase Talk & .304 & .141 & .287 & 2.160 & .040 \\
\hline & $\begin{array}{l}\text { Phase } \\
\text { Write }\end{array}$ & .499 & .138 & .463 & 3.612 & .001 \\
\hline
\end{tabular}

a. Dependent Variable: Literation Capabilities

The results of the analysis show that the Think Phase variable regression coefficient is 0.247 and is positive, with a significance probability of 0.043 . The probability of the significance of this variable is less than 0.05 , so it can be concluded that the Think Phase has a positive and significant effect on the improvement of literation capability in English text for students in semester 4 of the 2019/2020 academic year English Study Program, FKIP USI Pematangsiantar. Thus, the first hypothesis is accepted. 
The Talk Phase variable regression coefficient is 0.304 and is positive, with a significance probability of 0.040 . The probability of the significance of this variable is less than 0.05 , so it can be concluded that the Talk Phase has a positive and significant effect on the improvement of literation capability in English text for students in semester 4 of the 2019/2020 school year English study program, FKIP USI Pematangsiantar. Thus, the second hypothesis is accepted.

The regression coefficient for the Write Phase variable is 0.499 and is positive, with a significance probability of 0.001 . The probability of the significance of this variable is smaller than 0.05 , so it can be concluded that the Write Phase has a positive and significant effect on the improvement of literation capability in English text for students in semester 4 of the 2019/2020 school year English study program, FKIP USI Pematangsiantar. Thus, the third hypothesis is accepted.

\subsection{Discussion}

The results of the analysis show that the Think Phase, Talk Phase and Write Phase partially have a positive and significant effect on increasing literation capability. The Think phase, Talk phase and Write phase also influence literation capability simultaneously. This means that the development of the TTW Strategy that has been carried out has a positive and significant effect on increasing literation capability in English text for 4th semester students of the 2019/2020 academic year English Education study program, FKIP USI Pematangsianta. Implementation The development of the TTW Strategy can contribute to improving students' understanding and critical thinking capability.

The results of this study are in line with Zulkarnaini (2011) who argues that the cooperative learning model of the TTW type is an alternative to increase the intensity of student involvement effectively, especially in writing descriptive writing capability and critical thinking to achieve optimal achievement. The development of the TTW Strategy provides good things for students and teachers in improving literation capability in understanding with reading, conversation and writing materials in Explanation Text material.

\section{Conclusion}

This study aims to examine the influence of the development of TTW Strategy on increasing literation capability. The results of statistical tests show that the development of TTW Strategy has a significant effect in improving students' literation capability. This can be seen from the following conclusions:

1. The Think phase has a positive and significant effect on increasing literation capability in English text for 4th semester students of the 2019/2020 academic year English study program, FKIP USI Pematangsiantar .

2. The Talk phase has a positive and significant effect on increasing literation capability in English text for 4th semester students of the 2019/2020 academic year English study program, FKIP USI Pematangsiantar.

3. The Write phase has a positive and significant effect on increasing literation capability in English text for 4th semester students of the 2019/2020 academic year English study program, FKIP USI Pematangsiantar .

4. The Think Phase, Talk Phase, and Write Phase have a simultaneous effect on increasing literation capability in English text for 4th semester students of the 2019/2020 academic year English study program, FKIP USI Pematangsiantar 


\section{References}

Alderson, Charles and Lyle F. Bachman, Assessing Writing, (USA: Cambridge University Press, 2002 p. 116)

Andalusia, N (2017), Literasi Dini dan Teknik Bercerita. Jurnal Family Edu. Vol.III No.1 April.

Anderson, Mark Kathy Anderson. 1997. Text Types in English. Malaysia: Macmilan Education Ansari, Bansu I dan Martinis Yamin. (2012), Taktik Mengembangkan Kemampuan Individual Siswa, Jakarta: GP Press Group

APurba, A. et al. (2021) Pengajar Profesional: Teori dan Konsep. Yayasan Kita Menulis.

Darmayanti, Ni Luh Ita., A. Mahayukti, dan I Putu W. Ariawan. (2015), Pengaruh frekuensi pemberian tes formatif terhadap hasil belajar matematika siswa kelas Singaraja. Jurnal Pendidikan Matematika Undiksha. Vol. 3.

Erwinsah, et al. (2019). The Concept of School Literacy Movement Through Reading Time at SDIT Raudaturrahmah Pekanbaru. Budapest International Research and Critics in Linguistics and Education (BirLE) Journal. P. 145-157.

Fariah, N. dan Leonard (2017), Pengaruh frekuensi pemberian tes formatif terhadap hasil belajar matematika. Prosiding Diskusi Panel Nasional Pendidikan Matematik ke-3, Jakarta: 5 Agustus 2017

Hasmarani. Santi, dkk (2014), Pengaruh Strategi TTW pada Model Pembelajaran Problem Based Learning Terhadap Keterampilan Berpikir Kritis Siswa Kelas XI MS SMA Negeri 2 Bulukumba. Jurnal Chemica. Vol. 15 Nomor 14

Kompasiana, 29 Januari 2019 Laporan "World's Most Literate Nations", Indonesia Darurat Literasi Membaca

Permatasari, Ane (2015), Membangun kualitas bangsa dengan budaya Literasi. Prosiding Seminar Bulan Bahasa UNIB (Universitas Negeri Bengkulu)

Purba, A. and Girsang, S. E. E. (2020) 'The Use of Think Talk Write Strategy in Improving Students' Writing Spoof Ability on English Department FKIP USI Pematangsiantar', Budapest International Research and Critics Institute (BIRCIJournal): Humanities and Social Sciences, 3(3), pp. 2219-2223.

Ramadhani, Y. R. et al. (2020) Metode dan Teknik Pembelajaran Inovatif. Yayasan Kita Menulis tralia PTY LtD.

Ratih, Resna (2017), Penerapan Strategi Cooperative Learning Tipe TTW untuk Meningkatkan Aktivitas dan Hasil Belajar Siswa. Jurnal Pena Ilmiah. Vol. 2 No. 1.

Saragih, J.T., et al. (2019). The Effect of Reasoning Skills on Writing of Explanation Text Assessed from the Social Economic Status of Parents in Class VIII, SMP Negeri 2 Raya, Simalungun District, Indonesia. Budapest International Research and Critics in Linguistics and Education (BirLE) Journal. P. 78-87.

Sipayung, R.W. (2018) Improving Students' Achievement in Reading Descriptive Text through Reciprocal Teaching Strategy. Budapest International Research and Critics in Linguistics and Education (BirLE) Journal. P. 29-48

Tim GLN, Kemendikbud, 2017. Gerakan Literasi Nasional. Kementerian Pendidikan dan Kebudayaan: Jakarta.

Zulkarnaini (2011). Model Kooperatif Tipe TTW untuk Meningkatkan Kemampuan Menulis Karangan Deskripsi dan Berpikir Kritis. Jurnal Edisi Khusus. No.2. 